\title{
タクロリムス皮内濃度測定法の確立と経皮吸収基剤検討への応用
}

\author{
石井澄雄 $\dagger^{1}$ ，荒木博陽 ${ }^{*} \dagger^{1}$ ，三宅 悟 $\dagger^{1}$ ，二神幸次郎 $\dagger^{1}$ ，

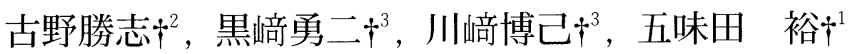 \\ 岡山大学医学部附属病院薬剂部 $\dagger 1$ \\ 岡山大学菌学部附属病院薬剤部 $\dagger^{2}$ \\ 岡山大学大学院自然科学研究科 $\dagger^{3}$
}

\section{Establishment of the Measuring Tacrolimus Concentration in the Skin, and Application to Study on the Vehicle for Percutaneous Absorption}

\author{
Sumio Ishii $\dagger^{1}$, Hiroaki Araki ${ }^{*} \dagger^{1}$, Satoru Miyake $\dagger^{1}$, Koujiro Futagami $\dagger^{1}$, Katushi Furuno $\dagger^{2}$, \\ Yuji Kurosaki $\dagger^{3}$, Hiromu Kawasaki ${ }^{3}{ }^{3}$ and Yutaka Gomita $\dagger^{1}$ \\ Department of Hospital Pharmacy, Okayama University Medical School $\dagger^{1}$ \\ Department of Hospital Pharmacy, Okayama University Dental School $\dagger^{2}$ \\ Department of Clinical Pharmaceutical Science, Graduate School of Natural \\ Science and Technology, Okayama University $\dagger^{3}$
}

$\left[\begin{array}{l}\text { Received April 10, } 2000 \\ \text { Accepted December 16, 2000 }\end{array}\right]$

\begin{abstract}
Tacrolimus (FK506) ointment has a good therapeutic effect on atopic dermatitis. The efficacy of Tacrolimus ointment, however, depends on the percutaneous adsorption of tacrolimus. To examine the influence of the ointment base on the percutaneous adsorption of tacrolimus, we performed a quantitative analysis of tacrolimus in the skin using an IMX (microparticle enzyme immunoassay) system. We prepared tacrolimus ointments using five kinds of ointment bases, i.e., Carbopol gel, White Petrolatum, Hydrophilic Ointment, Plastibase and Macrogol ointment. The concentration of tacrolimus in the rat abdominal skin were then determined 14 hours after the topical application of the different ointments to the rat skin by using the IMX system, and the effect of the various ointment bases was thus evaluated. As a result, the amount of tacrolimus in the skin measured 14 hours after topical application was as follows : Carbopol gel $>$ White Petrolatum $>$ Hydrophilic Ointment $\fallingdotseq$ Plastibase $>$ Macrogol ointment.
\end{abstract}

Keywords - percutaneous absorption, tacrolimus ointment, rat skin, carbopol gel, IMX

\section{緒言}

タクロリムス（FK506）は1984年に発見された放線菌 が産生するマクロライド系免疫抑制剤である。タクロリ
ムス軟膏は，アトピー性皮膚炎と乾癄に優れた臨床効果 があることがすでに確かめられている1). 局所から経皮 的に吸収されたタクロリムスの血中濃度は $1 \mathrm{ng} / \mathrm{mL}$ 以 下であり，懸念される全身作用に及ぼす影響はほとんど

$\dagger^{1,2}$ 岡山市鹿田町 2-5-1；2-5-1, Shikata-cho, Okayama-shi, 700-8558 Japan

$\dagger^{3}$ 岡山市津島中 $1-1-1 ; 1-1-1$, Tsushima-naka, Okayama-shi, 700-8530 Japan 
ない。また，その後のリバウンドは少なく，寛解期間が 比較的長く, さらにステロイド外用剂でみられる皮膚萎 縮作用がないなど種々の優れた特徴が報告されてい る2).そのため, 特にステロイド剤を投与した場合に副 作用の出現しやすい顔面や頸部の皮疹への適用が期待さ れている。

タクロリムスの血液中および尿中濃度の測定には, HPLC-MS 法, EIA (enzyme immunoassay) 法, 放射能力 ウント法, ELISA (enzyme linked immunosorbentassay) 法 などが用いられている3,4).しかしながら，これらの測 定方法については，迅速性，簡便性の点で問題があり， 測定時間の短縮化が求められている。こうした点を改善 した血中濃度測定法に, MEIA (microparticle enzyme immunoassay）の原理に基づいた IMX アナライザーを用い たIMX 法がある。この方法に抒けるタクロリムスの血 中濃度測定の信頼性は, $1.5 \mathrm{ng} / \mathrm{mL}$ から $30.0 \mathrm{ng} / \mathrm{mL}$ の間 ですでに確立されている。しかし，IMX 法を用いての 皮内濃度を測定した報告は見当たらない。そこで今回, 迅速かつ簡便である IMX 法を用いてタクロリムスの皮 内濃度の測定法を確立したので報告する。

ところで一方，軟膏剤による経皮吸収特性は，基剂に より異なることが知られている5). 河村らは, タクロリ ムス軟亨塗布時のラットに扔ける経皮吸収特性について 検討してお扔り, 軟膏中の主薬濃度 $(0.03,0.1,0.5 \mathrm{w} / \mathrm{w}$ \%）に依存して全血中タクロリムス濃度が上昇したこと を報告している6).タクロリムス軟膏の効力は経皮から の吸収性によるところが大きいと考えられるが，タクロ リムスの皮内移行動態に及ぼす軟膏基剂の影響に関する 試験は少ない. そこで今回, タクロリムスの皮内移行動 態に及ぼす軟膏基剤の影響を検討するため, 白色ワセリ ンを含め 5 種類の軟亳基剤を用いてタクロリムス含有軟 高を調製した，そして，今回確立したIMXアナライ ザーによる皮内濃度測定法（IMX 法）を用いて，ラッ 卜皮膚に塗布した後のタクロリムス皮内量を各軟膏基剤 ごとにそれぞれ測定した。

\section{実験材料および実験方法}

\section{1. 実験試料}

1) 試料

実験に使用した試料は以下の通りである。タクロリム 又標品(藤沢薬品工業(株)), タクロリムス注射液 (プロ グラフ ${ }^{\circledR}$ 注射液, 藤沢薬品工業(株)), 白色ワセリン (日 局, 油脂性基剂, 丸石製薬 (株)), 親水軟膏 (日局, 水中 油型乳剂性基剤，丸石製薬(株)), プラスチベース(日 局, 油脂性基剤, 大正製薬(株)), マクロゴール (日局, 水溶性基凨, 大日本製薬(株)), カーボポール $934 \mathrm{NP}$ (水
溶性ゲル基剤，BF Goodrich 社)，ヒドロキシプロピル セルロース，チオグリコール酸カルシウム三水和物（以 上, 和光純薬 (株)).

\section{2) 実験動物}

7 ～週令の Wistar 系雄性ラット（チャールス・リ バー）を使用した。

\section{2. 実験方法}

1) In vivo 経皮吸収試験

1-1 軟膏剤の調製

5 種の軟膏基剂（白色ワセリン，親水軟亳，プラスチ ベース，マクロゴール，カーボポールゲル）を用いて経 皮吸収性について検討した。これら各軟高基剤 $5 \mathrm{~g}$ に夕 クロリムス注射液 $(5 \mathrm{mg} / \mathrm{mL}) 1 \mathrm{~mL}$ を加え, 軟膏板で 均一になるまで十分に練合し，タクロリムスを $0.83 \mathrm{mg} /$ $\mathrm{g}$ 含有する各軟膏試料を調製した。なお，今回使用した カーボポールゲル基剤はカーボポール $934 \mathrm{NP} 0.08 \mathrm{~g}$ を水 $2.45 \mathrm{~g}$ とイソプロパノール $2.45 \mathrm{~g}$ の混液中に分散溶解さ せ，水溶性有機アミンであるトリスヒドロキシアミノメ タン $0.02 \mathrm{~g}$ で中和させた高粘度な透明ゲルである.

1-2 タクロリムスの皮内量測定方法の確立

1-2-1 血中濃度測定法による検討

サンプルとして全血液の代わりに皮膚から抽出された タクロリムスのメタノール溶液を用い, IMXアナライ ザー（ダイナパック社）を用いた方法でタクロリムスの 皮内量の測定を血中濃度測定と同様な方法で試みた。す なわち, 皮内から抽出された夕クロリムスのメタノール 溶液を血中濃度測定と同様に,「サンプル（メタノール 溶液）と除タンパク郕」を混合し，9500g（12000rpm） で 4 分間遠心分離後，上清をリアクションセルに移した 後, IMXアナライザー機器にセットし, 皮内中のタク ロリムス濃度の測定を行った（図1）。

1-2-2 モード 1 キャリブレーター $(0 \mathrm{ng} / \mathrm{mL}$, 薬 物無添加全血液）添加による検討

サンプルにモード1キャリブレーター $(0 \mathrm{ng} / \mathrm{mL}$ ，薬 物無添加全血液）を加える方法，すなわち「モード 1 キャリブレーター, サンプル（メタノール溶液）および 除タンパク剤」を混合し，(1-2-1）と同様に後処理 を行いIMX アナライザーを用いた方法（IMX 法）で皮 内濃度測定を行った。使用したモード1キャリブレー ターとは, $0 \mathrm{ng} / \mathrm{mL}$ の薬物無添加全血液であり, IMX アナライザーによる血中濃度測定時にブランクとして用 いられる（図 1).

1-3 In vivo 経皮吸収試験

ラットを麻酔し，腹部をはさみおよび除毛ゲルにて除 毛した。 2 日後, ラット腹部に O-リング (有効面積 
にて測定した．血液試料には IMXタクロリムス IIキャ

摘出した皮虐（はさみで細かく刻む）

$+$

メタノール / ヘキサン

振とう

遠心分離 $(3000 \mathrm{rpm}$ 10分間)

15分間）

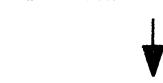

メタノール層をIMX 法用の

サンプル（メタノール溶液）とする

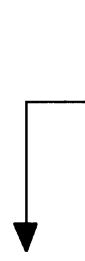

皮䖒から抽出された

メタノール溶液

$+$

除タンパク郕

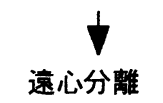

(12000rpm 4分間)

$\downarrow$

上清をIMXアナライザー

にて測定

\section{(1)血中粯度測定法}

による検討

図 1. 摘出皮膚からのタクロリムスの抽出方法㧍よび IMX 測定前処理

$\left.0.95 \mathrm{~cm}^{2}\right)$ をアロンアルファにに接着し，その部位に $0.83 \mathrm{mg} / \mathrm{g}$ 含有タクロリムス軟亳 $0.13 \mathrm{~g}$ を塗布した。軟 膏塗布14時間後にラットを放血致死させ，スパーテルで 軟亳をかきとった後，50\%メタノールを浸した脱脂綿に て塗布部位に残存した軟膏を除去した。 Oーリングの内 周に沿って皮膚を摘出し, 皮下脂肪を除去した後, 七口 テープで角質層のテープストリッピングを 20 回行った。 得られた皮虐試料を，はさみで細かく刻んだ後， $4 \mathrm{~mL}$ メタノール， $4 \mathrm{~mL}$ ヘキサンを加え, 320strokes/min で 15分間振とう後, 3000rpm で10分間遠心分離した。 メ夕 ノール層を $40^{\circ} \mathrm{C} て ゙$ 減圧濃縮し, 適量のメタノールを加え た後，(1-2）で確立したIMXアナライザーを用いた タクロリムス皮内量測定方法（IMX 法）にて定量した (図 1).

\section{$1-4$ 検量線}

既知量のタクロリムスを添加した皮膚試料から同様な 方法でタクロリムスを抽出し, IMXアナライザー機器
リブレーター $(0 ， 3 ， 6 ， 12 ， 20 ， 30 \mathrm{ng} / \mathrm{mL})$ を用いた。

2 ) 統計処理方法

得られた結果の各群間の統計的有意差の検定は Tukey の多重比較検定法を用いて行った。危険率 $5 \%$ 未満を有 意差ありと判定した。

\section{結果}

\section{1. 血中濃度測定法による検討}

皮内から抽出されたタクロリムスのメタノール溶液を IMX 法により血中濃度測定と同様な方法で測定を試み たが，測定不可能であった。

\section{2. モード 1 キャリブレーター $(0 \mathrm{ng} / \mathrm{mL}$, 薬物無添加} 全血液）添加による検討

サンプルにモード1キャリブレーターを加える方法, すなわち「モード1キャリブレーター, サンプル（メ夕 ノール溶液）抢よび除タンパク剂」を混合し， 1.と同 様に後処理を行った。

1 ）検量線㧍よび血中濃度と皮内濃度の定量精度の比 較

既知濃度のタクロリムスを含を血液試料と皮膚試料か ら調製した検量線用抽出試料の IMX 蛍光強度の变化を タクロリムス濃度の対数值に対しプロットしたものを比 較したところ, 図 2 に示す通り両者とも同様の良好な直 線性を示した。このことから, 皮膚からのタクロリムス 抽出率はほぼ100\%であると考えられる. 皮内濃度測定 に扮ける蛍光強度の変化の変動係数は $5 \%$ 以下であっ た。な扔，本報で用いた試料調製法に扔いて IMXによ るタクロリムスの定量範囲は $1.5 \sim 30.0 \mathrm{ng} / \mathrm{mL}$ であっ た。

2 ）タクロリムスの経皮吸収に及ぼす基剤の影響

各種軟膏をラット腹部に塗布し，14時間後の表皮㧍よ び真皮中の薬物量を図 3 に示した。なお，この軟高基剤 の影響は, 同一薬物濃度のタクロリムス軟膏を塗布し比 較した場合の結果である. 皮内中のタクロリムス量は カーボポールゲルを適用した際が最も多く, 次いで白色 ワセリンであった。プラスチベースと親水軟膏はほぼ同 量な值を示した．最も少なかったのはマクロゴールであ り，マクロゴールとカーボポールゲルおよび白色ワセリ ンの間で有意差（p<0.01，p<0.05）が認められた.

\section{考察}

IMX は，EIAの競合法に基づいた固定法（マイクロ パーティクル）を利用して検体（血液）中のタクロリム スを測定する方法である7゙. IMXを用いての血中濃度の 


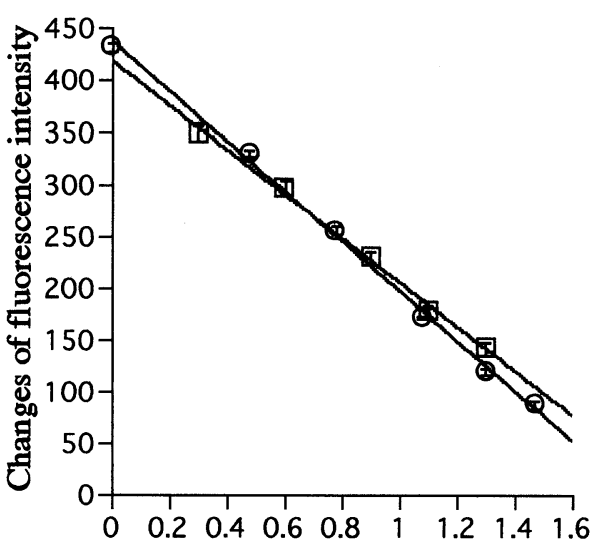

Amount of tacrolimus added to the sample (log $\mathrm{ng} / 0.95 \mathrm{~cm}^{2}$ tissue or mLwhole blood)

$$
\begin{array}{lll}
\square: \operatorname{skin}(n=3) & f(x)=-213 x+418 & r=0.998 \\
O: \operatorname{blood}(n=4) & f(x)=-240 x+440 & r=0.999
\end{array}
$$

図 2. ラット皮膚からとヒト全血液から抽出された タクロリムスの検量線の比較

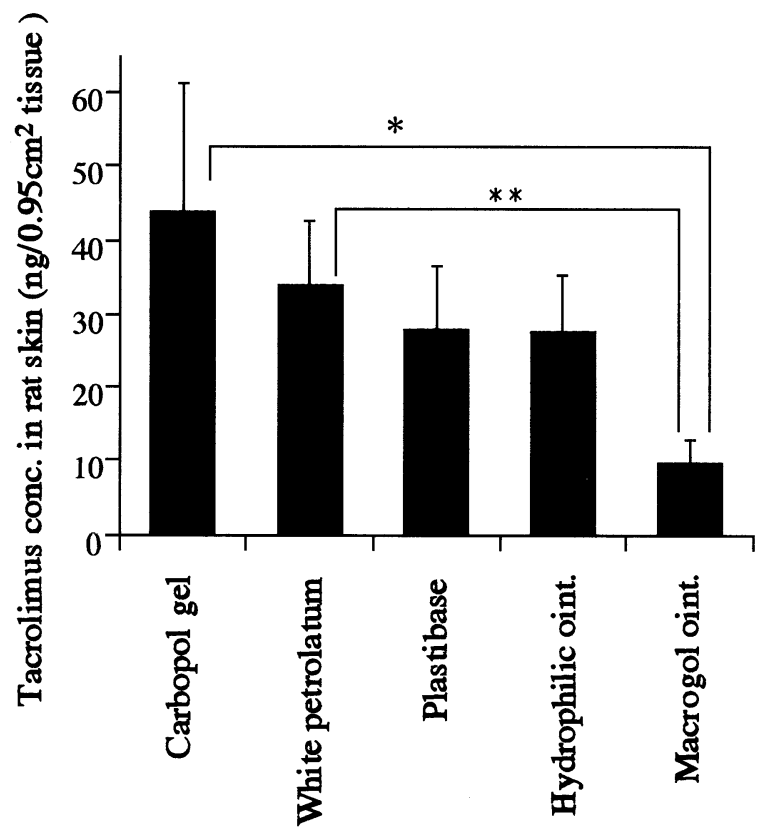

図 3. 異なる軟膏を塗布した後のラット皮膚中の タクロリムス濃度 $(\mathrm{n}=4)$ $\left.{ }^{*} ; \mathrm{p}<0.01,{ }^{* *} ; \mathrm{p}<0.05\right)$

測定はほぼ確立されているものの，血液以外の組織中の 測定法についてはまだ確立されていない，今回われわれ はタクロリムスの皮膚内含量の測定について検討した。 タクロリムスの血中濃度測定は, 全血液に除タンパク剤 を加えて混和, 後処理後測定する，タクロリムスの皮膚 濃度の測定についても，まず血中濃度の測定と同様な方
法で試みた。すなわちサンプルに全血液の代わりに皮虐 から抽出したタクロリムスのメタノール液を用い「サン プル(メタノール溶液) と除タンパク剤」を混合した後 処理を行う方法で測定を試みたが，測定不可であった。 そこで，サンプルにモード1キャリブレーター（薬物無 添加全血液）を加える方法により測定を行ったところ， タクロリムスの皮内濃度の測定が可能となった．皮内濃 度測定に打ける蛍光強度の变化の変動係数が $5 \%$ 以下 で, かつ皮内濃度拧よび血中濃度が同様の良好な直線性 を示したことょり，タクロリムスの皮内濃度測定法につ いてはモード 1 キャリブレーターを加えることにより血 中濃度測定法と同程度の精度で定量することが可能であ ることが明らかとなった。皮内濃度測定について，モー ド 1 キャリブレーターを加えず，血中濃度測定法と同様 な方法では測定ができなかった理由としては，使用する サンプルの中に血液が含有されていなかったためではな いかと推測される．IMXアナライザーは，タクロリム ス血中濃度測定のためだけに開発された機器であり, サ ンプルには血液のみを使用することになっている，その ため，今回のようにサンプルに血液を含有していないメ タノール溶液だけのものについては測定ができず，全血 液のモード 1 キャリブレーターを加えることで, 測定が 可能になったものと考えられる.

今回の検討では, 基剤として臨床でよく用いられる白 色ワセリン, プラスチベース, 親水軟膏, マクロゴー ル，およびカーボポールゲルを使用してタクロリムス軟 膏を調製し，タクロリムスの経皮吸収に及ほす影響を検 討した。カーボポールはアクリル酸架橋重合体（カルボ キシビニルポリマー）である。これをゲル化したカーボ ポールゲルは, カーボポールを水とイソプロパノールの 混液中に分散溶解させ，水溶性有機アミンで中和させた 高粘度な透明ゲルである，本剤の特色は，温度による粘 性変化がほとんどなく, ベとつかず延びがよいことであ る. 現在, カーボポールゲルが基剂に使用されている軟 亭の1つにインテバン®クリームがある．島らはこのイ ンドメタシンのカーボポールゲル基剤からの経皮吸収機 構について, カーボポールゲル基剤中の溶媒の蒸発によ りインドメタシンが基剤中で濃縮されて, 基剤からの薬 物放出性を高めると報告し ${ }^{8)}$ ，インドメタシンの皮膚内 移行率は, カーボポールゲル $>$ 吸水軟膏 $>$ 親水軟膏 $>$ 白 色ワセリン>プラスチベース>マクロゴールの順で, カーボポールゲル基剤は他の軟膏基剤に比べ吸収性の点 で優れているとしている。 また，Coldmanらは揮発性溶 媒と不揮発性溶媒からなる混合基剂を用いた薬物の経皮 吸収促進機構について検討し, 揮発性溶媒の蒸発に伴い 薬物が飽和溶解度以上の濃度で基剤中に溶解することに 
152

より，経皮吸収が促進されることを報告している9 らに，アルコール自身にも経皮吸収促進作用が知られて おり，例えばエタノールはエストラジオールやフェンタ ニル等の経皮治療システムに用いられている。エタノー ルの吸収促進機構としては, 角質層中の脂質の流動性克 進 $^{10)}$ や, 脱脂作用 ${ }^{111}$, 蛋白質構造の変化 ${ }^{12}$, エ夕ノール 自身の皮膚透過に伴う共輸送13) 等があげられる。今回 の実験で，軟膏を塗布し14時間後のタクロリムスの皮内 量は基剤にカーボポールゲルを適用したときが最も多 かった。しかし，14時間目の皮内濃度からだけでは， カーボポールゲルからのタクロリムスの皮内吸収動態を 判断したり，また製剤間で比較することはできない。そ のため，今後カーボポールゲルなどの基剤を使用した時 の, 経時的なタクロリムスの皮内濃度掞よび血中濃度を 測定し，それら製剤間に扔ける皮内吸収動態掞よび全身 作用についてさらに詳細な検討をする必要性があると思 われる。

\section{引用文献}

1）川島真，檜垣祐子，タクロリムス軟膏剤の皮虔刺 激性及びアトピー性皮膚炎における治療効果につ いて，アレルギー，42，1474(1993).

2）中川秀已，移植免疫抑制剂によるアトピー性皮虐 炎の治療，薬局，47，1137-1141(1996).

3) A. K. Gonschior, U. Christians, M. Winkler, H. M. Schiebel, A. Linck, and K. Fr. Sewing, Simplified high-performance liquid chromatography-mass spectrometry assay for measurement of tacrolimus and its metabolites and cross-validation with microparticle enzyme immunoassay, Therapeutic Drug Monitoring, 17, 504-510 (1995).

4) K. Iwasaki, H. Matsuda, T. Shiraga, A. Kawamura, Y. Miyazaki, Y. Teramura, Z. Tozuka, and T. Hata, Comparison of tacrolimus (FK506) levels determined by three different methods in the rat blood, 薬物動 態, 10, 837-847(1995).

5) T. Murakami, M. Yoshioka, I. Okamoto, R. Yumoto, Y. Higashi, K. Okahara, and N. Yata, Effect of ointment bases on topical and transdermal delivery of salicylic acid in rats : evaluation by skin microdialysis, J. Pharm. Pharmacol., 50, 55-61(1998).

6）河村章生, 寺村善則, 白神歳文, 宮崎由香子, 岩 崎一秀, 戸塚善三郎, 秦武久, FK506 軟膏塗布 時の動物に扩ける経皮吸収特性, 薬物動態, 11, suppl., S267 (1996).

7) 佐藤友啓, 結城祥充, 唯野貢司, 高橋保志, 竹内 一郎，平野哲夫， MEIA 改良法によるタクロリム 又全血中濃度測定の評価, 医学と薬学, 36, 14031407 (1996).

8) K. Shima, C. Matsusaka, M. Hirose, T. Noguchi, and Y. Yamahira, Biopharmaceutical characteristics of indomethacin gel ointment, Chem. Pharm. Bull., 29, 2338-2344 (1981).

9) M. F. Coldman, B. J. Poulsen, and T. Higuchi, Enhancement of percutaneous absorption by the use of volatile: nonvolatile systems as vehicles, J. Pharm. Sci., 58, 1098-1102(1969).

10) K. Knutson, S. L. Krill, and J. Zhang, Solventmediated alterations of the stratum corneum, J. Controlled Release, 11, 93-103(1990).

11) T. Kurihara-Bergstrom, K. Knutson, L. J. DeNoble, and C. Y. Goates, Percutaneous absorption enhancement of an ionic molecule by ethanol-water systems in human skin, Pharm. Res., 7, 762-766(1990).

12) B. Berner, R. Juang, and G. C. Mazzenga, Ethanol and water sorption into stratum corneum and model systems, J. Pharm. Sci., 78, 472-476 (1989).

13) P. Liu, T. Kurihara-Bergstrom, and W. R. Good, Cotransport of estradiol and ethanol through human skin in vitro: understanding the permeant/enhancer flux relationship, Pharm. Res., 8, 938-944(1991). 